\title{
Article
}

\section{Strategi Pemerintahan Desa Tanjung Alam Kecamatan Jangkat Timur Kabupaten Merangin Dalam Mengembangkan Wisata Telaga Biru}

\author{
Joko Setyoko ${ }^{1^{*},}$ Ristarnado ${ }^{2}$
}

This article is an open access article distributed under the terms and conditions of the Creative Commons Attribution-ShareAlike 4.0 International (CC BY SA ) License (https://creativecommo ns.org/licenses/by$\underline{\mathrm{sa} / 4.0 /) \text {. }}$

\section{Jurnal Politik dan} Pemerintahan Daerah ISSN 2686-2271

Fakultas Ilmu Sosial dan Ilmu Politik, Universitas Muara Bungo Jl. Diponegoro No. 27, Muara Bungo-Jambi, (0747) 323310

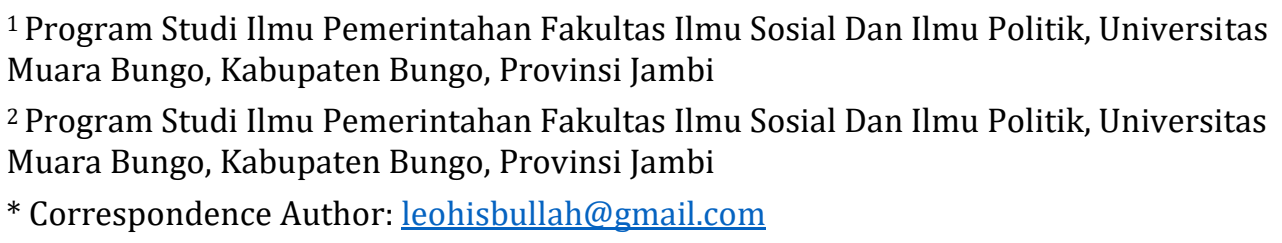

${ }^{1}$ Program Studi Ilmu Pemerintahan Fakultas Ilmu Sosial Dan Ilmu Politik, Universitas Muara Bungo, Kabupaten Bungo, Provinsi Jambi

${ }^{2}$ Program Studi Ilmu Pemerintahan Fakultas Ilmu Sosial Dan Ilmu Politik, Universitas Muara Bungo, Kabupaten Bungo, Provinsi Jambi

* Correspondence Author: leohisbullah@gmail.com

Abstract: The research was conducted in Tanjung Alam Village, Jangkat Timur District, Merangin Regency. This location was chosen purposively, that is, on purpose. With the consideration that Tanjung Alam village is a village where Telaga Biru tourism is located and the development of Telaga Biru tourism is one of the Tanjung Alam village's RPJM in realizing the welfare of the surrounding community and Telaga Biru Tourism is the Regional Original Income (PAD) of Tanjung Alam village. This research was conducted from February 2018 to March 2018. This study aims to determine the strategies and constraints of the Tanjung Alam Village government, Jangkat Timur District, Merangin Regency in developing Telaga Biru tourism. The results of the study indicate that related to the dimensions of the strategy, namely: Objectives, Policies and Programs carried out by the Village Government are included in the Strategy. The Tanjung Alam village government strategy in developing Blue Lake tourism is the provision of blue lake tourism facilities and infrastructure, additional promotion plans, formation of permanent management, coordination with the tourism support sector, implementation of domestic tourism promotion, and training of tour guides. The obstacles faced by the Tanjung Alam village government in developing Tanjung Alam tourism are limited funds, the low quality of human resources (human resources) for managers and the role of the Merangin Regency Regional Government which has not been active in supporting the provision of facilities and infrastructure for tourism activities.

Keywords: Strategy, Blue Lake Tourism and Village Government

Abstrak: Penelitian dilaksanakan di Desa Tanjung Alam Kecamatan Jangkat Timur Kabupaten Merangin. Lokasi ini dipilih secara "purposive" yaitu dengan sengaja. Dengan pertimbangan bahwa desa Tanjung Alam merupakan desa tempat pariwisata Telaga Biru dan pengembangan wisata Telaga Biru merupakan salah satu RPJM desa Tanjung Alam dalam mewujudkan kesejahteraan masyarakat sekitar dan Pariwisata Telaga Biru merupakan pendapatan Asli Daerah (PAD) desa Tanjung Alam. Penelitian ini dilakukan pada bulan Februari 2018 sampai Maret 2018. penelitian ini bertujuan untuk mengetahui strategi dan kendala pemerintah Desa Tanjung Alam Kecamatan Jangkat Timur Kabupaten Merangin dalam mengembangkan pariwisata Telaga Biru. Hasil penelitian menunjukkan bahwa terkait dengan dimensi-dimensi strategi yakni : Tujuan, Kebijakan dan Program yang dilakukan Pemerintahan Desa termasuk ke dalam Strategi. Adapun strategi pemerintahan desa Tanjung Alam dalam pengembangan wisata Telaga Biru yaitu penyediaan sarana dan prasarana wisata telaga biru, rencana tambahan promosi, pembentukan pengurus tetap, koordinasi dengan sektor pendukung pariwisata, pelaksanaan promosi pariwisata nusantara terutama di dalam 
negeri dan pelatihan pemandu wisata. Kendala yang dihadapi pemerintahan desa Tanjung Alam dalam pengembangan wisata Tanjung Alam adalah keterbatasan dana, rendahnya kualitas SDM (sumber daya manusia) pengelola dan Peran Pemerintah Daerah Kabupaten Merangin yang belum aktif dalam mendukung penyediaan sarana dan prasarana kegiatan wisata.

Kata Kunci :Strategi, Wisata Telaga Biru dan Pemerintahan Desa

\section{Pendahuluan}

Indonesia adalah salah satu negara di dunia yang menyimpan banyak potensi alam yang melimpah baik daratan maupun lautan. Berlimpahnya sumber daya alam yang ada dapat meningkatkan pertumbuhan ekonomi ketika sumber daya tersebut dapat di kelola dengan baik sesuai dengan apa yang paling diminati masyarakat sehingga pemanfaatan sumber daya alam tersebut tidak akan menghabiskan waktu ataupun materi akibat ketidakberhasilan dalam mengelola suatu sumber daya. Pariwisata merupakan salah satu pemanfaatan sumber daya alam yang dapat bernilai ekonomi tinggi bagi suatu daerah yang mengelola sumber daya alam menjadi suatu tempat wisata yang dapat menarik pengunjung baik dari dalam maupun dari luar negeri.

Pariwisata merupakan salah satu industri baru yang mampu menyediakan pertumbuhan ekonomi yang cepat dalam hal kesempatan kerja, pendapatan, taraf hidup dan dalam mengaktifkan sektor produksi lain di dalam negara penerima wisatawan. Disamping bernilai ekonomi yang tinggi, pariwisata dapat menumbuhkan dan meningkatkan rasa bangga terhadap bangsa sehingga akan tumbuh masyarakat yang lebih peduli terhadap suatu bangsa. Pariwisata juga sangat potensial untuk membangun dan mengembangkan suatu kawasan, baik di lingkungan perkotaan maupun perdesaan. Selain itu, sektor pariwisata juga memberikan multiplier effect dan nilai manfaat yang besar bagi masyarakat, seperti menciptakan lapangan pekerjaan baru dan menurunkan angka pengangguran (Hadiwijoyo, 2012).

Dalam era globalisasi sekarang ini, bidang pariwisata merupakan salah satu kegiatan yang mempunyai peranan yang sangat strategis dalam menunjang pembangunan perekonomian nasional. Sektor ini dicanangkan selain sebagai salah satu sumber penghasil devisa yang cukup andal, juga merupakan sektor yang mampu menyerap tenaga kerja dan mendorong perkembangan investasi. Bank Indonesia (BI) menyatakan bahwa sektor pariwisata merupakan sektor paling efektif untuk meningkatkan devisa negara karena sumberdaya yang dibutuhkan untuk mengembangkan sektor ini terdapat di Indonesia (Rahma, 2020)._Disamping kebermanfaatan pariwisata sebagai sumber devisa, pariwisata juga berkontribusi dalam penciptaan lapangan kerja, kegiatan produksi dan pendapatan nasional (PDB), serta pertumbuhan sektor swasta dan pembangunan infrastruktur (Nizar, 2011). Untuk mengembangkan sektor ini pemerintah berusaha keras membuat rencana dan berbagai kebijakan yang mendukung kearah kemajuan sektor ini. Salah satu kebijakan tersebut adalah menggali, menginventarisir dan mengembangkan obyek-obyek wisata yang ada sebagai daya tarik utama bagi wisatawan.

Kabupaten Merangin merupakan salah satu kabupaten di Propinsi Jambi yang memiliki beragam sumber daya alam dan budaya sebagai objek daya tarik wisata. Kabupaten Merangin menjadi salah satu tujuan wisatawan di Provinsi Jambi yang memiliki potensi wisata alam yang sangat indah, baik dari alam maupun budaya dari daerah itu sendiri. Seperti gunung, danau, air terjun, air panas, goa, geopark dan berbagai wisata modern yang kini tengah dikembangkan. Hal ini tentu dapat 
memberikan kontribusi untuk peningkatan pendapatan daerah melalui kunjungan wisatawan ke sejumlah objek wisata yang ada di sana.

Salah satu objek wisata yang menarik di Kabupaten Merangin yaitu Telaga Biru yang berada di Desa Tanjung Alam Kecamatan Jangkat Timur. Telaga biru ini memberikan sensasi keindahan alam yang khas yaitu warnanya yang biru dan sangat jernih hingga tembus kedasar telaga serta kesejukan udara karena rimbunnya pepohonan disekitar telaga ini. Telaga biru berada diketinggian 2033 Mdpl di kawasan Hutan Produksi Lainnya (HPL) yang berbatasan langsung dengan Taman Nasional Kerinci Seblat (TNKS). Perjalanan menuju telaga biru dapat ditempuh dengan berjalan kaki selama lebih kurang 7 jam atau menggunakan kendaraan roda dua yang hanya memakan waktu 3 jam perjalanan dari desa Tanjung Alam Jangkat Timur. Selama perjalanan mata kita akan disuguhkan dengan pemandangan perbukitan, persawahan yang menghampar luas ditambah bunyi gemercik air dari aliran irigasi sawah serta kebun kopi yang berada disepanjang jalan yang hanya dilengkapi depondok peristirahatan petani yang bisa digunakan oleh wisatawan untuk beristirahat saat hendak mengunjungi telagabiru. Walaupun demikian tidak mudah bagi wisatawan untuk dapat sampai ke Telaga Biru karena perjalanan menembus dalamnya hutan adat dengan jalanan curam, menanjak, menurun, melewati tingginya pepohonan yang dilapisi lumut.

Pemerintah selaku pejabat yang berwenang harus memberikan perhatian lebih pada objek wisata yang berpotensial menghasilkan pendapatan dan mengarahkan sektor ini sebagai investasi yang menguntungkan kedepannya serta memberikan asumsi yang baik bagi para wisatawan dalam kemudahan prosedur untuk mengikat daya tarik. Namun tidak hanya pendapatan bagi pemasukan pemerintah tapi juga kesejahteraan untuk masyarakat di sekitar objek wisata. Penanganan objek wisata pada peningkatan sumberdaya manusia yang memadai secara konsisten, menyeluruh, terpadu dan sistematis oleh Pemerintah kepada masyarakat perlu dilakukan karena keberhasilan upaya-upaya strategi pengembangan dan pengelolaan kegiatan pariwisata merupakan suatu tindakan, baik itu tindakan pemerintah, swasta maupun masyarakat sehingga terciptanya kerjasama yang baik dan harmonis dan mewujudkan sapta pesona.

Keberadaan sektor pariwisata dalam suatu wilayah dapat memberikan dampak positif maupun negatif. Namun, pada dasarnya tergantung pada manajemen dan tata pengelolaan kepariwisataan yang diperankan oleh segenap pemangku kepentingan (stakeholders) baik dari unsur pemerintah-industri masyarakat yang ada pada wilayah tersebut. Pencapaian tujuan dan misi pembangunan kepariwisataan yang baik, berkelanjutan (sustainable tourism) dan berwawasan lingkungan hanya akan dapat terlaksana manakala dalam proses pencapaiannya dapat dilakukan melalui tata kelola kepariwisataan yang baik (good tourism governance) (Yoeti, 2006).

Undang-Undang mengenai Otonomi Daerah telah disyahkan pemerintah dengan persetujuan DPR RI, pada tanggal 4 Mei 1999, dan mulai diberlakukan secara efektif pada tahun 2001. Untuk merealisasikan Undang-Undang Otonomi Daerah tersebut, Departemen Dalam Negeri telah mengeluarkan buku pedoman tentang Visi, Misi, Strategi dan Kebijakan Pemberdayaan Masyarakat Desa, sebagai pegangan bagi aparat pemerintah di daerah. Menurut pedoman tersebut, pada pokoknya pemberdayaan masyarakat mempunyai dua makna pokok, yaitu :

1. Meningkatkan kemampuan masyarakat melalui pelaksanaan berbagai kebijakan program pembangunan.

2. Meningkatkan kemandirian masyarakat melalui pemberian wewenang secara proporsional kepada masyarakat dalam mengambil keputusan. Dari penjelasan tersebut, jelas masyarakat diberi kesempatan penuh dalam perencanaan dan pelaksanaan pembangunan. Disitu ditegaskan bahwa tugas birokrasi di daerah hanyalah sebagai fasilitator (pelayanan). Kreativitas 
masyarakat dipacu dan didorong berkembang. Kemudian Departemen Pariwisata dalam kiprah memberdayakan masyarakat desa telah menyusun program pembangunan desa.

Dihubungkan dengan pedoman Visi, Misi, Strategi dan Kebijakan Pemberdayaan Masyarakat desa tersebut di atas, pembangunan desa wisata ini nampaknya sangat relevan dengan pedoman tersebut. Dengan demikian pembangunan desa wisata dapat dikatakan merupakan tindak lanjut dari pelaksanaan Undang-Undang Otonomi Daerah. Untuk semakin mewujudkan semangat otonomi daerah hingga pada level pemerintahan desa dan untuk mengatasi berbagai permasalahan yang terjadi dalam wilayah desa dan mewujudkan kemandirian serta kesejahteraan bagi wilayah desa maka pemerintah pada Tahun 2014 mengeluarkan kebijakan perundang-undangan baru yaitu Undang-Undang Nomor 6 Tahun 2014 tentang Desa. Munculnya undang-undang desa tersebut semakin memberi keleluasaan kepada desa untuk melakukan perencanaan, pengawasan, pengendalian dan mengevaluasi kebijakan-kebijakan yang dikeluarkan oleh desa.

Dari uraian diatas perlu disadari oleh pemerintah daerah terutama pemerintah desa Tanjung Alam yang berperan penting dalam mengembangkan desa sehingga dapat mengangkat ekonomi desa apabila setiap obyeknya dikelola dengan baik oleh pemerintah maupun pihak-pihak disekitar obyek wisata tersebut sehingga banyaknya kunjungan wisatawan akan berpengaruh pada naiknya pendapatan desa. Solusi-solusi yang dimaksud dalam hal ini adalah strategi terkait dengan pengembangan objek wisata Telaga Biru agar dapat lebih berdaya saing dalam menarik wisatawan. Strategi sebagai bentuk upaya yang dilakukan untuk menciptakan dan melestarikan kawasan wisata dengan menggunakan dimensi-dimensi strategi yang menciptakan strategi yang sesuai dengan pengembangan kawasan obyek wisata Telaga Biru ini. Sehingga dengan demikian pemerintah desa Tanjung Alam dapat mengambil langkah yang strategis dari pilihan yang ada.

Meskipun desa Tanjung Alam sangat berpotensi sebagai desa wisata, namun berbagai kendala yang harus dihadapi pemerintah desa Tanjung Alam dalam pengembangan wisata Telaga biru adalah infrastruktur yang kurang baik seperti kondisi jalan menuju Telaga Biru yang butuh perjuangan dengan kondisi curam dan dan berbatu, terbatasnya fasilitas pendukung seperti tempat penginapan yang belum tersedia yang akan mengurangi nilai (value) yang didapatkan wisatawan menjadi hambatan pelaksanaan kegiatan pariwisata di Desa Tanjung Alam. Wisatawan masih enggan untuk mengunjungi ataupun berlama-lama berada di desa ini karena segala sesuatu yang mungkin mereka butuhkan belum tersedia. Hal ini juga yang dapat memicu rendahnya angka wisatawan yang berkunjung ulang sebagai repeater tourist. Pada dasarnya pengembangan pariwisata di Desa Tanjung Alam sangat penting untuk dilakukan. Pengembangan pariwisata di Desa Tanjung Alam akan memberikan perubahan dan keberlangsungan baik jangka pendek maupun jangka panjang bagi masyarakat lokal dan pemerintah Merangin.

Adanya berbagai permasalahan tersebut maka pemerintah desa Tanjung mempunyai strategi untuk dalam mengatasi hal tersebut yaitu memanfaatkan Undang-Undang Nomor 6 Tahun 2014 sebagai langkah awal dalam pengembangan wisata Telaga biru dengan memamfaatkan dana desa untuk pengembangan potensi yang dimiliki yaitu sebagai desa wisata. Karena UU Nomor 6 Tahun 2014 beserta peraturan pelaksanaannya telah mengamanatkan pemerintah desa untuk lebih mandiri dalam mengelola pemerintahan dan berbagai sumber daya alam yang dimiliki, termasuk di dalamnya pengelolaan keuangan dan kekayaan milik desa seperti objek Telaga Biru yang terdapat di Desa Tanjung Alam ini. Sejalan dengan strategi tersebut di atas maka dalam pengelolaan sumber daya alam pedesaan melalui pelibatan masyarakat desa dalam mengelola dan memanfaatkan sumber 
daya alam di Desa Tanjung Alam maka pemerintahan desa Tanjung Alam telah megeluarkan Perdes No. 01/2016 dan Perkepdes 2017 No. 01/KDS tentang objek wisata Telaga Biru di kawasan hutan adat Desa Tanjung Alam. Adapun data statistik pengunjung objek wisata Telaga Biru dapat dilihat pada tabel 1.

Tabel 1. Data Statistik Pengunjung Objek Wisata Telaga Biru Desa Tanjung Alam

\begin{tabular}{c|c|c} 
Tahun & Jumlah Pengunjung ( Orang ) & Uang Masuk ( Rp ) \\
2014 & 600 & 3.500 .000 \\
2015 & 800 & 4.075 .000 \\
2016 & 900 & 6.010 .000 \\
2017 & 1010 & 14.000 .000
\end{tabular}

Sumber : Kantor Desa Tanjung Alam, 2017

Strategi menjadi sangat penting bagi pengembangan sebuah organisasi/ perusahaan dalam rangka pencapaian tujuan, baik tujuan jangka pendek maupun jangka panjang. Analisa dalam pengembangan strategi berdasarkan dimensi-dimensi strategi yang digunakan yaitu Tujuan, Kebijakan dan Program. (Mintzberg \& Quinn, 2003). Oleh karena itu, penyusunan strategi merupakan langkah taktis yang bersifat sistematis dalam pencapaian tujuan organisasi. Berdasarkan uraian diatas maka penulis begitu tertarik untuk melakukan penelitian dengan judul : "Strategi Pemerintahan Desa Tanjung Alam Dalam Mengembangkan Wisata Telaga Biru (Studi Kasus Desa Tanjung Alam Kecamatan Jangkat Timur Kabupaten Merangin)".

\section{Pembahasan}

\section{Strategi Pengembangan Pemerintahan desa Tanjung AlamKonstituen}

Sebagaimana dengan metode yang digunakan dalam penelitian ini yaitu metode kualitatif yang menganalisis lebih mendalam terhadap data-data yang diperoleh. Data yang dimaksud dalam hal ini yaitu wawancara yang dilakukan pada pihak-pihak yang dianggap berkompeten terhadap permasalahan dalam fokus penelitian. Dalam hal ini adalah pengembangan obyek wisata pariwsata Telaga Biru di desa Tanjung Alam Kabupaten Merangin Kecamatan Jangkat Timur yang berfokus pada desa Tanjung Alam yang mempunyai tugas melaksanakan urusan pemerintahan, kepentingan masyarakat setempat berdasarkan prakarsa masyarakat, hak asal usul dan/atau hak tradisional yang diakui dan dihormati dalam sistem pemerintahan NKRI.

Selanjutnya hasil penelitian yang dilakukan penulis, akan dibagi berdasarkan fokus masalah yang dibahas terkait dengan teori yang digunakan yaitu Dimensi Strategi menurut Henry Mintzberg, Joseph Lampel, James Brian Quinn, dan Sumantra Ghoshal (2003) dalam buku The Strategy Process yaitu: Tujuan, Kebijakan dan Program yang akan menghasilkan suatu strategi. Pemerintahan Desa Tanjung Alam terhadap pengembangan kawasan Telaga Biru adalalah Strategi sebagai Rencana, karena Kepala Desa Tanjung Alam selaku yang bertanggung jawab penuh terhadap segala urusan kebudayaan dan kepariwisataan di desa Tanjung Alam ini, yang menetapkan arah organisasi menjadi lebih baik dengan berbagai perencanaan yang disusun secara matang dan segala Tujuan, Kebijakan dan Program yang dilakukan Pemerintahan Desa Tanjung Alam yang dikembangkan secara sadar dan sengaja sesuai dengan pengertian Strategi sebagai Rencana yakni : Strategi adalah rencana, semacam sadar dimaksudkan yang meliputi tindakan, pedoman (atau pedoman yang ditetapkan) untuk menangani situasi.

Dengan definisi ini, strategi memiliki dua karakteristik penting: mereka dibuat sebelum tindakan yang menerapkan, dan mereka dikembangkan secara sadar dan sengaja. Sebagai rencana, strategi berkaitan dengan bagaimana pemimpin mencoba untuk menetapkan arah untuk organisasi, untuk mengatur 
mereka pada tindakan yang telah ditentukan. Adapun strategi tersebut adalah sebagai berikut :

\section{Penyediaan Sarana dan Prasarana Wisata Telaga Biru}

Kebijakan yang akan dilakukan pemerintahan desa Tanjung Alam dalam mengembangkan objek wisata Telaga Biru adalah penyediaan sarana dan prasaran atau faktor fasilitas dan infrastruktur yaitu jalan utama menuju objek wisata Telaga Biru. Fasilitas dan infrastruktur menuju objek wisata Telaga biru termasuk kedalam Accessibility atau aksesibilitas, seperti akses jalan raya, ketersediaan sarana transportasi dan rambu-rambu penunjuk jalan merupakan bagian aspek pendukung kelancaran menuju objek wisata tersebut. Ada beberapa cara menuju objek wisata Telaga Biru yaitu berjalan kaki yang memakan waktu selama 7 jam dan menggunakan kendaraan roda 2 yang hanya memakan waktu waktu 3 jam dari desa Tanjung Alam.kualitas jalan menuju arah Telaga Biru sampai saat yang belum memadai dan masih belum beraspal serta tanda jalan atau rambu-rambu petunjuk arah menuju objek wisata belum ada sehingga hal ini menjadi kendala yang harus secepatnya dibangun mengingat bertambahnya peminat atau pengunjung objek wisata Telaga Biru.

Kebijakan adalah rangkaian keputusan yang membimbing dan membatasi tindakan yang dilakukan. Berdasarkan hasil wawancara dengan kepala desa Tanjung Alam Bapak Pahlepi Sahreza, ketika ditanya tentang kebijakan-kebijakan yang apa yang dikeluarkan pemerintah desa dalam pengembangan objek wisata Telaga Biru.

Adanya akses yang mudah menuju lokasi wisata tentu akan meningkatkan nilai tambah tersendiri selain beberapa kemudahan atau keunggulan potensi alam yang sudah dimiliki oleh desa wisata tersebut. Keberhasilan dalam proses pengembangan suatu wisata tidak dapat dilepaskan dari adanya campur tangan sebuah lembaga atau institusi lokal yang mengelola wisata tersebut. Institusi lokal ini yang menjadi perpanjangan tangan dari berbagai stake holder yang terhubung langsung dan tak langsung dengan semua aktivitas pariwisata di desa.

Kebijakan-kebijakan yang telah ditetapkan tentunya akan melahirkan program-program sebagai kumpulan kegiatan-kegiatan nyata dan terpadu serta berkesinambungan guna pengembangan obyek wisata. Program pengembangan pariwisata yang diantaranya berfokus pada pengembangan dari segi fisik, pengembangan ini sangat perlu dilakukan karena segi fisik adalah gambaran nyata dimana kita dapat menilai suatu tempat dengan melihat dengan jelas bentuk dan segala sesuatu secara nyata.

Salah satu item pembenahan dalam pengembangan obyek wisata adalah perbaikan sarana dan prasarana. Seperti diketahui sarana dan prasarana yang baik dan lengkap merupakan nilai tambah dan hal yang dapat meningkatkan nilai keindahan suatu obyek wisata. Keindahan serta keunikan suatu obyek wisata harus mampu didukung dengan sarana dan prasarana yang baik pula guna menunjang para wisatawan untuk menikmati keindahan obyek wisata tersebut. Walaupun suatu obyek wisata memiliki keindahan alam yang menakjubkan namun tidak didukung oleh pembangunan sarana dan prasarana untuk menikmatinya maka sama saja wisatawan tidak dapat mengeksplorasi lebih jauh lagi obyek wisata tersebut.

Sarana dan prasarana merupakan salah satu obyek kepuasaan pengunjung terhadap suatu kawasan obyek wisata yang dikunjungi. Sarana dan prasarana yang dapat memuaskan seperti akses jalan, WC, maupun sarana yang menunjang keindahan dan kepuasan wisatawan jika tidak dilakukan pembenahan sesuai dengan standar bagi kenyamanan pengunjung maka kawasan obyek wisata belum dapat dikatakan sebagai kawasan obyek wisata yang dapat menarik minat 
pengunjung dikarenakan adanya ketidakpuasan pengunjung terhadap sarana dan prasarana tersebut. Program pemerintah dalam pengembangan Tanjung Alam dalam hal ini pembenahan terkait sarana dan prasarana seperti, akses jalan, WC, pemeliharaan pintu gerbang, pembuatan Mushalah dan sarana dan prasarana lainnya merupakan langkah yang tepat guna menunjang kepuasaan pengunjung terhadap kawsasan obyek wisata Telaga Biru, sehingga harus terealisasi secepatnya.

Fasilitas pariwisata merupakan pelengkap pada daerah tujuan wisata yang merupakan faktor penting untuk membuat wisatawan nyaman dan aman ketika berwisata. Dalam melaksanakan pembangunan prasarana wisata perlu disesuaikan dan mempertimbangkan kondisi dan lokasi yang akan meningkatkan aksesibilitas suatu objek wisata yang pada waktunya dapat meningkatkan daya tarik objek wisata itu sendiri.

Keseluruhan yang dimaksud adalah pengembangan objek wisata yang dipandang sebagai sesuatu yang utuh dan bukan merupakan kesatuan dari bagianbagian yang terpisah. Langkah awal yang dilakukan pemerintahan desa Tanjung Alam dalam pengembangan objek wisata Telaga Biru secara fisik adalah dengan membuka akses jalan beserta rambu jalan sebagai petunjuk arah sehingga pengunjung tidak merasa gelisah ataupun was-was sampai ke lokasi Telaga Biru. Pengembangan secara keseluruhan yang pengerjaan awalnya tefokus pada satu titik yaitu akses jalan menuju objek wisata Telaga Biru dan pada saat pembangunan akses jalan berlangsung pemerintahan desa juga akan melakukan pengembangan terhadap sumber daya manusia yaitu terhadap masyarakat sadar wisata disekitar desa Tanjung Alam serta para pemuda dengan melakukan pelatihan-pelatihan.

Kepala urusan Pembangunan desa Tanjung Alam yang juga mempunyai peran yang besar di dalam meningkatkan sebuah kawasan obyek wisata yang membuat kawasan wisata tersebut dapat diketahui oleh para wisatawan salah satunya dengan penyediaan sarana dan prasarana wisata tersebut.

Pembenahan yang dimaksud adalah perbaikan yang dilakukan menyangkut jasa pengembangan kawasan obyek wisata Tanjung Alam agar menarik wisatawan untuk berkunjung. Sebelum melakukan pembenahan/perbaikan, tentunya pemerintah harus melakukan analisis pasar terhadap obyek wisata tersebut. Analisis dilakukan agar mengetahui hal apa yang kurang serta dapat dikembangkan guna meningkatkan ketertarikan calon wisatawan yang akan berkunjung.

\section{Tambahan Promosi}

Selanjutnya setelah pembenahan selesai dilaksanakan, maka hal yang juga penting dilakukan dalam mengembangkan obyek wisata adalah dengan melakukan promosi yang gencar. Promosi adalah pengenalan yang dilakukan terkait obyek wisata Telaga Biru yang berupa penyebaran informasi melalui segala media informasi dan komunikasi sehingga segala hal yang ada di kawasan obyek wisata Telaga Biru dapat terekspose dan menarik wisatawan. Selain itu promosi pariwisata yang merupakan ujung tombak dalam mengenalkan, menginformasikan, dan mencitrakan suatu obyek wisata juga telah dilakukan namun sebelum melakukan promosi lebih jauh pemerintahan desa Tanjung Alam melakukan pembenahan-pembenahan terlebih dahulu sehingga promosi akan lebih efektif karena pembenahan telah dilakukan. Bagaimanapun indah dan menariknya suatu obyek wisata di suatu tempat, namun tanpa adanya promosi yang gencar dari pemerintah maupun pengelola obyek wisata tersebut, maka obyek wisata tersebut tak akan dijamah oleh wisatawan.

Selain sarana dan infrastruktur kebijakan yang akan dilakukan adalah promosi yang sangat berpengaruh bagi pengembangan objek wisata Telaga Biru, faktor 
promosi juga memiliki pengaruh yang cukup besar bagi tercapainya pembangungan desa wisata yang mampu meningkatkan perekonomian masyarakatnya. Promosi merupakan upaya untuk memberitahukan atau menawarkan produk maupun jasa dengan tujuan untuk menarik calon konsumen untuk membeli atau mengonsumsinya. Manajemen promosi yang baik dan benar akan menjadikan produk maupun jasa tersebut menarik dan mampu membuat konsumennya merasa menginginkannya. Salah satu indikator dari kebijakan pengembangan pariwisata adalah promosi sebagai pelaksanaan upaya pemasaran yang selaras dan terpadu. Pemasaran merupakan kegiatan yang sangat penting, sehingga pembeli mendapat keuntungan maksimal dengan resiko sekecilkecilnya. Selain itu juga ada aksesbilitas, sebagai pengembangan lintas sektoral, dan pengembangan kawasan pariwisata dan produk pariwisata (Suwantoro, 2004).

Promosi merupakan salah satu faktor penentu keberhasilan suatu program pemasaran. Bagaimanapun berkualitasnya suatu produk, bila konsumen belum pernah mendengarnya dan tidak yakin bahwa produk itu akan berguna bagi mereka, maka mereka tidak akan pernah membelinya. Pada hakikatnya promosi adalah suatu bentuk komunikasi pemasaran. Sedangkan komunikasi pemasaran itu sendiri adalah aktivitas pemasaran yang berusaha menyebarkan informasi, mempengaruhi/membujuk, dan mengingatkan pasar sasaran atas perusahaan dan produknya agar bersedia menerima, membeli dan loyal pada produk yang ditawarkan perusahaan yang bersangkutan (Tjiptono, 2008).

\section{Pembentukan Pengurus Tetap}

Wisata Telaga Biru adalah aset dan program yang di prioritas pengembangannya oleh pemerintahan desa Tanjung Alam namun pengelolaan wisata Telaga biru sangatlah lemah, hal ini dapat dilihat dari perlengkapan maupun fasilitas yang tersedia belum tampak keberadaannya. Meskipun pengelolaan yang lemah namun pada dasarnya wisata Telaga Biru sangat berarti bagi masyarakat di desa Tanjung Alam dan memberikan dorongan yang berarti untuk pembangunan desa Tanjung Alam kedepannya. Prinsip pengembangan desa wisata adalah sebagai salah satu produk wisata alternatif yang dapat memberikan dorongan bagi pembangunan pedesaan yang berkelanjutan serta memiliki prinsip-prinsip pengelolaan antara lain, ialah: (1) memanfaatkan sarana dan prasarana masyarakat setempat, (2) menguntungkan masyarakat setempat, (3) berskala kecil untuk memudahkan terjalinnya hubungan timbal balik dengan masyarakat setempat, (4) melibatkan masyarakat setempat, dan (5) menerapkan pengembangan produk wisata pedesaan (Sastrayuda, 2010), dan beberapa kriteria yang mendasarinya seperti antara lain:

a. Penyediaan fasilitas dan prasarana yang dimiliki masyarakat lokal yang biasanya mendorong peran serta masyarakat dan menjamin adanya akses ke sumber fisik merupakan batu loncatan untuk berkembangnya desa wisata.

b. Mendorong peningkatan pendapatan dari sektor pertanian dan kegiatan ekonomi tradisional lainnya.

c. Penduduk setempat memiliki peranan yang efektif dalam proses pembuatan keputusan tentang bentuk pariwisata yang memanfaatkan kawasan lingkungan dan penduduk setempat memperoleh pembagian pendapatan yang pantas dari kegiatan pariwisata.

d. Mendorong perkembangan kewirausahaan masyarakat setempat. (Sastrayuda, 2010)

Ramuan utama desa wisata diwujudkan dalam gaya hidup dan kualitas hidup masyarakatnya. Keaslian juga dipengaruhi keadaan ekonomi, fisik dan sosial daerah pedesaan tersebut, misalnya ruang, warisan budaya, kegiatan pertanian, 
bentangan alam, jasa, pariwisata sejarah dan budaya, serta pengalaman yang unik dan eksotis khas daerah. Dengan demikian, pemodelan desa wisata harus terus dan secara kreatif mengembangkan identitas atau ciri khas daerah.

Ramuan penting lainnya dalam upaya pengembangan desa wisata yang berkelanjutan yaitu pelibatan atau partisipasi masyarakat setempat, pengembangan mutu produk wisata pedesaan, pembinaan kelompok pengusaha setepat. Keaslian akan memberikan manfaat bersaing bagi produk wisata pedesaan. Unsur-unsur keaslian produk wisata yang utama adalah kualitas asli, keorisinalan, keunikan, ciri khas daerah dan kebanggaan daerah diwujudkan dalam gaya hidup dan kualitas hidup masyarakatnya secara khusus berkaitan dengan prilaku, integritas, keramahan dan kesungguhan penduduk yang tinggal dan berkembang menjadi milik masyarakat desa tersebut.

Pada dasarnya tujuan pengembangan setiap kawasan wisata yang ada di Kabupaten Merangin khususnya kawasan obyek wisata Telaga Biru memberikan manfaat atau keuntungan bagi pemerintah, wisatawan dan terutama warga/ masyarakat setempat. Dari pernyataan Kepala desa dan Sekretaris desa dapat dijelaskan bahwa pengembangan yang dilakukan pemerintahan desa selain untuk melestarikan kawasan wisata juga dapat menunjang perekonomian masyarakat kecil sehingga pengembangan yang dilakukan sangat bermanfaat bagi pemerintah, wisatawan dan terutama masyarakat perekonomian kecil dimana mereka dapat menumbuhkan pendapatan ekonomi mereka. Pengembangan adalah usaha atau cara untuk memajukan serta mengembangkan sesuatu yang sudah ada. Pengembangan pariwisata pada suatu daerah tujuan wisata selalu akan diperhitungkan dengan keuntungan dan manfaat bagi masyarakat yang ada di sekitarnya. Pengembangan pariwisata harus sesuai dengan perencanaan yang matang sehingga bermanfaat baik bagi masyarakat, baik juga dari segi ekonomi, sosial dan juga budaya. (Yoeti, 2008)

Dalam hal pengembangan potensi wisata Telaga Biru, pengembangan potensi wisata akan membuat pendapatan asli daerah meningkat. Hal ini disebabkan seiring pengembangan potensi wisata dalam hal ini Telaga Biru dilakukan, maka secara otomatis pelayanan administrasi, sarana prasarana, dan produk pariwisata khas Telaga Biru akan ditingkatkan guna menarik pengunjung / wisatawan untuk berkunjung ke tempat wisata ini. Dengan usaha-usaha pengembangan tersebut di atas maka sesuai dengan harapan akan terjadi kenaikan jumlah wisatawan yang akan berdampak pada penjualan tiket (retribusi) yang akan berkontribusi pada peningkatan jumlah Pendapatan Asli Desa Tanjung Alam. Di dalam konsep pengembangan, juga terdapat penjualan makanan khas maupun souvenir yang tentu akan menggerakkan perekonomian lokal daerah tersebut. Usaha Mikro Kecil Menengah (UMKM) juga akan tumbuh sehingga pemberdayaan masyarakat lokal akan berdampak positif. Konsep pengembangan Telaga Biru yang menjadi tempat wisata nyaman dengan segala pelayanan, keindahan, keramah tamahan penduduk asli dan cinderamata yang ditawarkan akan langsung berdampak pada kenaikan pendapatan asli desa secara signifikan.

Tak sampai disitu, selain meningkatkan jumlah wisatawan, merebaknya Usaha Mikro Kecil Menengah (UMKM), serta peningkatan dalam hal Pendapatan Asli Daerah, pengembangan objek wisata khususnya pada Telaga Biru juga akan semakin meningkatkan kesadaran masyarakat akan penghargaan terhadap budaya dan kelestarian alam setempat. Selain itu, jika hal ini terus dipertahankan dan ditingkatkan maka bukan hal mustahil daerah di sekitar Telaga Biru akan menjadi daerah wisata yang mandiri.

Berdasarkan tujuan akhir dari pengembangan wisata Telaga Biru yaitu untuk meningkatkan perekonomian masyarakat setempat, maka pengembangan wisata 
Telaga Biru harus dikelola secara profesional dengan tidak mengesampingkan kelestarian sumberdaya alam yang ada. Pengemasan dan paket wisata perlu direncanakan dan dikelola dengan baik agar suatu wisata mempunyai nilai jual terhadapwisatawan. Paket-paket yang ditawarkan diharapkan mampu memberikan sebuah tantangan yang tidak dapat ditemukan di desa wisata lainnya. Hal inilah yang perlu dipikirkan dalam pengembangan desa wisata, karena masa sekarang desa wisata sangat banyak ragamnya dan jumlahnya di Kabupaten Merangin. Apabila tidak ditawarkan kekhasan wisata Tanjung Alam yang dikembangkan maka nasibnya akan sama dengan desa wisata lainnya, yaitu hanya slogan sebagai desa wisata akan tetapi tidak ada kegiatan wisata di desa tersebut. Kerjasama dengan berbagai pihak dan dinas terkait diperlukan untuk pengembangan desa wisata, misalnya tour and travel, dinas pariwisata daerah, pengembangan promosi melalui web/internet, media komunikasi, dan pemasaran yang lain. Hal ini akan mendukung terciptanya iklim wisata yang kondusif yang tidak menimbulkan konflik kepentingan yang merugikan desa wisata.

Tujuan merupakan hasil yang ingin dicapai suatu organisasi/instansi. Penetapan tujuan dan sasaran Jangka Menengah Pembangunan kepariwisataan di desa Tanjung Alam didasarkan pada bidang-bidang strategis. Tujuan kepariwisatan menggambarkan arah strategi dan perbaikan-perbaikan yang ingin diciptakan.

Peran pemerintahan desa dalam mengembangkan obyek wisata merupakan syarat mutlak dalam memajukan potensi wisata yang dimiliki desa tersebut, hal ini dikarenakan dalam dasawarsa terakhir ini banyak negara berkembang menaruh perhatian yang khusus terhadap industri pariwisata. Hal ini jelas kelihatan dengan banyaknya program pengembangan kepariwisataan di negara tersebut. Penggalian potensi wisata di desa Tanjung Alam saat ini telah dilaksanakan secara bertahap oleh pemerintah desa Tanjung Alam, banyaknya potensi yang dimiliki menjadi modal awal dalam menambah Pendapatan Asli Desa (PADes) dari sektor pariwisata. Dengan demikian potensi yang dimiliki dapat dikembangkan sebagai aktivitas perekonomian dalam membangun obyek wisata Telaga Biru menjadi sesuatu yang mudah untuk dapat menghasilkan PADes. Berbagai upaya dilakukan oleh Ninik Mamak, Kepala Desa dan masyarakat Desa Tanjung Alam Kecamatan Jangkat Timur Kabupaten Merangin untuk menjaga dan melestarikan hutan tanah dan air sebagai sumber kehidupan mereka di desa. Hasilnya kondisi hutan ulayat sangat baik dengan kondisi hutan lebat. Dengan berbagai aktifitas perlindungan lingkungan yang dikembangkan masyarakat Desa Tanjung Alam upaya pencegahan penebangan liar dan pencemaran.

Kebijakan-kebijakan yang akan dijalankan oleh Pemerintah dalam hal ini Pemerintahan desa Tanjung Alam dalam pengembangan obyek wisata Telaga Biru secara keseluruhan telah direncanakan dan sudah dirembukan dengan pemerintahan desa dan BPD yang terbukti dari ungkapan BPD dan sekretaris desa. BPD sudah menjalankan fungsi dan wewanangnya yaitu BPD berfungsi menetapkan peraturan Desa bersama kepala desa, menampung dan menyalurkan aspirasi masyarakat dan berwewenang menggali, menampung, menghimpun, merumuskan dan menyalurkan aspirasi masyarakat, membahas rancangan peraturan desa bersama kepala desa dalam pengembangan objek wisata Tanjung Alam in.

Pengembangan wisata Telaga Biru merupakan keinginan masyarakat Desa Tanjung dan telah disepakati oleh pemerintahan desa sesuai prosedur yang berlaku yaitu dengan melakukan musyawarah desa dan telah dicatat oleh sekretaris desa meskipun belum diundangkan dan telah disetujui oleh pemerintahan desa dan BPD desa Tanjung Alam. Sehingga dengan musyawarah desa dan atas kesepakatan bersama tersebut pengembangan Telaga Biru menjadi Rencana jangka menengah desa Tanjung Alam. Untuk mewujudkan keinginan masyarakat tersebut maka 
peran pemerintahan desa dalam mengembangkan obyek wisata merupakan syarat mutlak dalam memajukan potensi wisata yang dimiliki desa tersebut dan membutuhkan strategi sehingga dengan strategi yang direncanakan dapat bermanfaat bagi masyarakat sekitar baik secara ekonomi, sosial maupun budaya dan menjadi modal awal dalam menambah Pendapatan Asli Desa (PADes) dari sektor pariwisata.

4. Koordinasi Dengan Sektor Pendukung Pariwisata

Program adalah berupa urutan-urutan tindakan yang dilakukan untuk mencapai tujuan yang ditetapkan. Adapun program-program yang akan dilakukan pemerintahan desa Tanjung Alam dalam bidang kepariwisataan salah satunya adalah koordinasi dengan sektor pariwisata. Dalam mengembangkan suatu obyek wisata tentunya Pemerintah desa membutuhkan peran pihak lain guna membantu dalam hal promosi dan pemasaran pariwisata dengan melaksanakan program pemanfatan teknologi informasi. Tentunya program-program yang berkaitan untuk mempromosikan obyek wisata sangat dibutuhkan bagi pengembangan obyek wisata khususnya obyek wisata yang belum terlalu terkenal dan masih dalam tahap pengembangan.

Pengembangan suatu desa wisata merupakan bagian dari penyelenggaraan pariwisata yang terkait langsung dengan jasa pelayanan, yang membutuhkan kerjasama dengan berbagai komponen penyelenggara pariwisata yaitu pemerintah, swasta, dan masyarakat. Masyarakat yang merupakan salah satu komponen yang penting dalam hal ini, karena desa wisata dapat berjalan dengan baik dan lancar ketika ada dukungan dari masyarakat itu sendiri. Dalam mengembangkan objek wisata Telaga Biru sangat penting dibutuhkan peran aktif dari masyarakat sekitar. Karena secara tidak langsung upaya pengembangan pariwisata daerah akan berdampak juga pada peningkatan kesejahteraan masyarakat sekitar itu sendiri.

Guna menjaga hubungan kemitraan, diperlukan pula peningkatan koordinasi sesama stakeholder baik pihak Pemerintah, pihak Swasta, pihak lembaga yang berkaitan dengan kebudayaan dan pariwisata, pihak masyarakat serta pihak lainnya yang terlibat dalam kemitraan ini. Pemantauan dan evaluasi dari setiap tahap yang dilalui patut dijalankan secara konsisten dan sistematis guna mencapai tujuan maksimal dari kemitraan pengembangan obyek wisata Telaga Biru.

Pengembangan wisata Telaga Biru di Desa Tanjung Alam mengusung konsep tradisional dengan melibatkan masyarakat lokal untuk berpartisipasi langsung sebagai manajemen pengelola. Pada tahap perintisan wisata Telaga Biru, peran Pemerintah Desa sangatlah menetukan dalam mencapai keberhasilan. Pemerintah Desa Tanjung Alam merumuskan strategi pengembangan wisata Telaga Biru dengan meningkatkan kapasitas (capacity building) dari seluruh elemen stakeholder yang terlibat baik itu Pemerintah Desa, organisasi lokal dan masyarakat lokal. Pengembangan kapasitas dan kemampuan (capacity building) yang digagas oleh Pemerintah Desa Tanjung Alam adalah ingin meningkatkan kinerja secara optimal untuk menunjang pencapaian target pembangunan ekonomi, pembenahan SDM, meningkatkan kemampuan individu dalam rangka mewujudkan pengembangan wisata Tanjung Alam berbasis masyarakat.

\section{Pelaksanaan Promosi Pariwisata Nusantara Terutama di Dalam Negeri}

Dalam menjalankan program terkait pengembangan objek wisata Telaga Biru, pemerintahan desa Tanjung harus melibatkan para stakeholder dan berbagai pihak yang ada serta bekerjasama dengan pihak swasta, masyarakat dan pemerhati lingkungan. Dalam membangun kemitraan dengan pihak swasta dan lainnya, maka diperlukan pula pengembangan dan penguatan terhadap informasi dan database 
sebagai data awal potensi dan kekayaan alam dalam hal ini keindahan obyek wisata Telaga Biru guna sebagai bahan kajian bagi Pemerintah dan mitranya terhadap pengembangan obyek wisata tersebut. Langkah atau strategi selanjutnya yang harus dilakukan pemerintahan desa Tanjung Alam dalam pengembangan wisata Telaga Biru adalah pelaksanaan promosi nusantara di dalam negeri.

Kebijakan pemerintahan desa Tanjung Alam dalam hal promosi diharapkan mampu membantu pariwisata di desa Tanjung Alam khususnya objek wisata Telaga Biru untuk lebih dapat dikenal tidak hanya oleh masyarakat di Kabupaten Merangin saja, tetapi juga masyarakat luar dan diharapkan mampu bersaing dengan pariwisata di daerah lain. Dalam pengembangan daya tarik wisata, diperlukan dukungan promosi dan publikasi yang baik apalagi pada era global seperti sekarang ini publikasi dapat dilakukan dengan mudah melalui internet. Pemerintah daerah diharapkan mampu merencanakan pembangunan pariwisata hingga memasarkan objek wisata yang ada khususnya di desa Tanjung Alam, karena kurangnya pembaruan informasi mengenai kepariwisataan di daerah ini dibutuhkan strategi promosi yang baik agar visi dan misi pariwisata daerah dapat terwujud.

Dengan adanya program-program yang menyangkut promosi tersebut, tentunya obyek-obyek wisata Desa Tanjung Alam maupun yang ada di Kabupaten Merangin umumnya dapat lebih dikenal dan menarik wisatawan dari dalam maupun luar negeri. Namun sampai saat penelitian berlangsung konsep pentingnya promosi dalam memasarkan pariwisata yang ada di desa Tanjung Alam ini terutama objek wisata Telaga Biru, belum pernah tersentuh oleh promosi apapun, promosi yang direncanakan pemerintahan desa hanya sebatas rencana.

Berdasarkan penjelasan yang diungkapkan di atas bahwa kebijakan promosi adalah kebijakan yang akan dilakukan namun promosi pariwisata yang dilakukan masih amat rendah atau tidak gencar bahkan tidak ada promosi karena masih banyaknya akses, fasilitas dan perlengkapan pariwisata yang harus dibenahi terutama akses jalan, penginapan, atraksi wisata selain itu kurangnya pembaruan mengenai informasi pariwisatanya sedangkan jumlah kunjungan wisatawan baik lokal maupun domestik mengalami kenaikan setiap tahunnya.

Peranan pemasaran pariwisata dapat meningkatkan pengetahuan dan kesadaran pemangku kepentingan pariwisata, terutama pangsa pasar utama terhadap upaya pelestarian produk-produk wisata secara berkelanjutan. Strategi pemasaran menyediakan kerangka kordinasi, sehingga para pemangku kepentingan pariwisata yakni Dinas Pariwisata yang bertanggung jawab terhadap objek-objek wisata akan memiliki arah yang sama dalam upaya pengembangan mengelola destinasi dan mempromosikan pariwisata di daerahnya.

Meskipun dari pihak pemerintahan desa sendiri belum pernah melakukan promosi namun pada situs-situs tertentu secara tidak langsung sudah mempromosikan tentang objek wisata Tanjung Alam ini. Seperti yang diungkapkan oleh salah satu yang menyatakan bahwa selama perjalanan mata kita akan disuguhkan dengan pemandangan perbukitan, persawahan yang menghampar luas ditambah bunyi gemercik air dari aliran irigasi sawah serta kebun kopi yang berada disepanjang jalan yang dilengkapi pondok peristirahatan petani yang bisa digunakan oleh wisatawan untuk beristirahat saat hendak mengunjungi telagabiru dikatakan bahwa selama perjalanan sudah ada. http://www.thejambitimes.com/2017/04/telaga-biru-di-merangin.html)

Berdasarkan uraian tentang pelaksanaan promosi pariwisata nusantara terutama di dalam negeri maka menurut penulis itu, pemerintah perlu menggencarkan forum-forum dialog dan komunikasi antar sesama pelaku industri dan budaya agar dapat lebih mudah menemukan strategi guna mengidentifikasi 
potensi yang masih bisa dikembangkan guna meningkatkan kualitas pariwisata di Kecamatan Jangkat khususnya Telaga Biru. Suatu hal yang sering dijumpai bahwa ide-ide serta gagasan cemerlang biasanya hadir dalam dialog-dialog serta forum komunikasi tak terkecuali terhadap strategi pengembangan obyek wisata.

\section{Pelatihan Pemandu Wisata}

Pelatihan terhadap pemandu wisata adalah salah kegiatan pokok dalam program pengembangan pemasaran Pariwisata. Munculnya proses partisipasi dalam rangka pemberdayaan masyarakat mendasarkan atas dua perspektif. Pertama : Pelibatan masyarakat, setempat dalam pemilihan, perancangan, perencanaan dan pelaksanaan program yang akan mewarnai kehidupan masyarakat, sehingga dengan demikian dapatlah dijamin bahwa persepsi setempat, pola sikap dan pola pikir serta nilai-nilai pengetahuannya ikut dipertimbangkan secara penuh. Ke-dua : membuat umpan balik yang pada hakikatnya merupakan bagian yang tidak terlepaskan dari kegiatan pembangunan. Masyarakat dapat diajak terlibat guna mengarahkan perencanaan dan program pemodelan desa wisata dalam kerangka pembangunan desa secara keseluruhan yang berintikan ; (1) desa tempat dimana pemerintahan desa menjalankan pemerintahannya, (2) desa tempat dimana penduduk desa menjalankan pola kehidupan dan keagamaannya dan berkumpul dalam satu harmonisasi kehidupan yang mencerminkan tata karma masyarakat, (3) desa tempat dimana masyarakat desa melakukan kegiatan waktu luang dan berekreasi bercengkerama di alam desa yang mereka miliki, (4) desa dimana masyarakat memiliki sikap, prilaku melindungi, memelihara dan memanfaatkan kepemilikan seni budaya, lingkungan, nilai-nilai tradisi yang dapat mendorong kelestarian promosi desa itu sendiri .

Sumber daya manusia merupakan salah satu modal dasar dalam upaya pengembangan pariwisata. Sumber daya manusia dalam bidang kepariwisataan harus memiliki keahlian dan memiliki keterampilan untuk memberikan pelayanan pariwisata serta menangani berbagai permasalahan kepariwisataan dan berbagai persoalan yang ada. Berhasilnya suatu pembangunan dan pengembangan sektor pariwisata di desa Tanjung Alam juga tergantung pada kemampuan para pelaksana yang bertugas pada tempat-tempat daerah tujuan wisata maupun aparat pelaksana pengembangan sektor pariwisata.

Salah satu strategi utama yang disusun oleh pemerintahan desa Tanjung Alam adalah Pengembangan Sumber Daya Manusia dimana poin penting dalam pengembangan sumber daya manusia yang dimaksud itu diantaranya : pengembangan akan profesionalisme sumber daya manusia dengan mengadakan pelatihan dan pendidikan. Pengetahuan dan keterampilan dari masyarakat maupun pemuda sangat dibutuhkan untuk dapat mengembangkan desa wisata, namun masyarakat dan pemuda di desa Tanjung Alam memiliki pengetahuan dan keterampilan yang terbatas dan pemikiran-pemikiran yang belum luas namun mereka punya semangat dan kesadaran yang tinggi terhadap pengembangan wisata Telaga Biru, sehingga mereka butuh pelatihan-pelatihan, namun pelatihanpelatihan yang diharapkan tidak kunjung di dapatkan karena belum adanya konfirmasi dari pihak terkait dalam bidang kepariwisataan.

Pemberdayaan masyarakat dalam konteks pengembangan pariwisata merupakan upaya penguatan dan peningkatan kapasitas, peran dan inisiatif masyarakat sebagai salah satu stakeholder penting di luar unsur pemerintah dan swasta, untuk dapat berpartisipasi dan beran aktif dan strategi sebagai subyek maupun sebagai penerima manfaat dalam pengembangan kepariwisataan secara berkelanjutan (Suyanto, 2012). Mengingat hal tersebut di atas, maka pemerintahan desa telah membuat kebijakan meskipun belum diundangkan tapi sudah tercatat sebagai Rencana Pembangunan Jangka Menengah (RPJM) desa Tanjung Alam. 
pengembangan obyek wisatanya secara bertahap dan menyeluruh dengan fokus terhadap pengembangan satu obyek wisata dan selanjutnya melangkah ke pengembangan obyek wisata itu sendiri yaitu berupa perlengkapan-perlengkapan wisata seperti WC, atraksi wisata, tempat penginapan, dan prasarana wisata lainnya.

Masyarakat adalah penggerak utama dalam desa wisata. Masyarakat itu sendiri yang mengelola pariwisata tersebut. Masyarakat menjadikan rumah-rumah mereka atau sebagian kamar-kamar mereka menjadi tempat tinggal tamu sementara (homestay) dalam suatu desa wisata. Akan menjadi komplit apabila tamu-tamu bisa menikmati keseharian rakyat (live in), merasakan sajian makan dan jenis atraksi kebudayaan desa.

Obyek Telaga Biru merupakan kawasan wisata yang dapat menunjang pendapatan asli desa Tanjung Alam. Pengembangan yang dilakukan yakni pembangunan secara holistik. Holistik atau holisme adalah suatu pemikiran yang menyatakan bahwa sistem alam semesta, baik yang bersifat fisik, kimiawi, hayati, sosial, ekonomi, mental psikis dan kebahasaan, serta segala kelengkapannya harus dipandang sebagai sesuatu yang utuh dan bukan merupakan kesatuan dari bagian-bagian yang terpisah. (wikipedia.org /wiki/holism.)

Dalam penelitian yang dilakukan penulis terhadap strategi pengembangan yang dilakukan Pemerintahan Desa Tanjung Alam Kecamatan Jangkat Timur Kabupaten Merangin terkait dimensi-dimensi strategi yang dikemukakan oleh Mitzberg, dkk yakni : Tujuan, Kebijakan dan Program yang akan menghasilkan suatu strategi dari lima definisi strategi yang dikemukakan (Mintzberg, Lampel, Quinn, Ghoshal. The Strategy Process. Edisi Keempat. New Jersey: Upper Saddle River. 2003.). Berdasarkan Kebijakan, Program Tujuan yang akan dilaksanakan Pemerintahan Desa Tanjung Alam terhadap pengembangan kawasan obyek wisata Telaga Biru harus dilakukan secara keseluruhan dan terfokus pada satu titik sehingga pengembangan yang dilakukan dapat membuahkan hasil yang maksimal.

\section{Kendala Pemerintahan Desa Tanjung Alam Dalam Pengembangan Wisata Telaga Biru}

Wisata Telaga Biru merupakan salah potensi desa yang dimiliki desa Tanjung Alam dan strategi baik berupa tujuan, kebijakan dan program sedang dilaksanakan secara bertahap oleh pemerintah desa Tanjung Alam, dalam membangun obyek wisata Telaga Biru menjadi sesuatu yang mudah untuk dapat menghasilkan PADes tidak semudah apa yang direncakan. Berbagai kendala yang dihadapi pemerintah desa Tanjung Alam dalam upaya pengembangan wisata Telaga Biru Desa Tanjung Alam Kecamatan Jangkat Timur Kabupaten Merangin. kendala yang dihadapi pemerintahan desa Tanjung Alam dalam mengembangkan wisata Tanjung Alam adalah:

1. Keterbatasan dana

Dana khusus untuk dana wisata dari pemerintahan pusat untuk pengembanagan wisata Telag biru tidak ada sedangkan untuk pengambangan desa wisata ini butuh dana yang sangat besar, dana yang desa yang ada di desa Tanjung Alam bukan untuk pengembangan wisata melainkan dana untuk pembangunan desa pada umumnya.

2. Rendahnya kualitas SDM (sumber daya manusia) pengelola

Rendahnya kualitas SDM (sumber daya manusia) pengelola menjadi kendala pengembangan wisata Telaga Biru sebagai potensi desa Tanjung Alam. Hal ini disebabkan sebagian besar masyarakat di Desa Tanjung Alam hanya berpendidikan sekolah dasar. Sehingga pelaksanaan program-program 
kegiatan harus dilakukan dengan sosialisasi dan penyuluhan yang membutuhkan waktu lama.

Sumber daya manusia merupakan salah satu modal dasar dalam upaya pengembangan pariwisata. Sumber daya manusia dalam bidangkepariwisataan harus memiliki keahlian dan memiliki keterampilan untuk memberikan pelayanan pariwisata serta menangani berbagai permasalahan kepariwisataan dan berbagai persoalan yang ada. Berhasilnya suatu pembangunan dan pengembangan sektor pariwisata juga tergantung pada kemampuan para pelaksana yang bertugas pada tempat-tempat daerah tujuan wisata maupun aparat pelaksana pengembangan sektor pariwisata, yakni aparat Dinas Kebudayaan dan Pariwisata itu sendiri.

Salah satu strategi utama yang disusun oleh pemerintahan desa Tanjung Alam adalah strategi pengembangan Sumber Daya Manusia dimana poin penting dalam pengembangan sumber daya manusia yang dimaksud itu diantaranya : Pengembangan akan profesionalisme sumber daya manusia pengelola dengan mengadakan pelatihan dan pendidikan, namun rencana ini belum terlaksana. Pengelola objek wisata memanng tidak ada pengalaman ataupun ilmu yang ahli dalam kepariwisataan sedangkan untuk pelatihan sendiri juga baru sebatas rencana saja, itulah yang menjadi kendala bagi kita sdm disini bahwa masih di butuhkan tenaga ahli yang berlandaskan ilmu khusus. Kedepannya mungkin sudah bisa lebih baik lagi karena kita berharap sudah bisa menjalin kerjasama dengan pihak swasta seperti investor dan sponsor.

Peran Pemerintah Daerah Kabupaten Merangin yang belum aktif dalam mendukung penyediaan sarana dan prasarana kegiatan wisata serta belum memberikan bantuan secara finansial yang dirintis oleh Pemerintah Desa Tanjung Alam.

Peran Pemerintah Daerah Merangin yang masih pasif ini sangat menghambat pembangunan wisata Tanjung Alam. Padahal jika ditinjau, pengembangan wisata Tanjung Alam memerlukan rencana strategis yang menghubungkan intruksi kepariwisataan secara menyeluruh. Kurang aktifnya atau tidak adanya kejelasan peran pemerintahan Kabupaten Daerah Kabupaten Merangin dalam pengembangan wisata Telaga Biru tidak menyurutkan langkah pemerintahan desa Tanjung Alam dalam mengembangkan objek wisata Telaga Biru dengan harapan kedepannya, pemerintahan Daerah Kabupaten Merangin tergugah untuk ikut serta dalam pengembangan wisata yang ada di desa Tanjung Alam terutama objek wisata Tanjung Alam.

\section{Implementasi Strategi sebagai Rencana}

Beberapa implementasi strategi yang dilakukan Perintahan desa Tanjung Alam terkait strategi yang teridentifikasi yaitu Strategi sebagai Rencana dengan melihat potensi dari obyek wisata Talaga Biru adalah :

1. Pengembangan yang dilakukan terfokus pada satu titik agar kiranya pengembangan yang dilakukan akan terlihat hasilnya.

2. Melibatkan semua elemen-elemen yang terkait dengan pengembangan yang akan dilakukan sehingga pengembangan tersebut dapat kita lakukan dengan membuahkan hasil maksimal yang diharapkan bersama.

3. Mengidentifikasi secara menyeluruh terhadap obyek yang akan dikembangkan agar dapat menyusun segala perencanaan dengan sebaikbaiknya.

4. Melakukan pelatihan-pelatihan baik pemandu wisata, pelaku wisata dan pengelolah wisata.

5. Koordinasi yang terus dilakukan kepada pemerintah dan warga sekitar kawasan obyek wisata. 
Adapun sumber daya yang mendukung pengembangan kawasan obyek wisata Telaga Biru ini adalah sebagai berikut :

1. Keindahan alam yang masih terbilang alami yang dikelilingi pohonpohon yang rimbun dan suasana yang begitu menyejukkan.

2. Sarana dan prasarana yang sudah ada seperti jalan setapak, akses jalan dan bangunan-bangunan yang lain.

3. Keterlibatan semua elemen-elemen yang dapat menunjang pengembangan kawasan obyek wisata Telaga Biru

\section{Penutup}

Berdasarkan hasil penelitian dan pembahasan penulis pada uraian sebelumnya maka dapat ditarik kesimpulan sebagai berikut (1)Terkait dengan dimensi-dimensi strategi yakni : Tujuan, Kebijakan dan Program yang dilakukan Pemerintahan Desa termasuk ke dalam Strategi. Adapun strategi pemerintahan desa Tanjung Alam dalam pengembangan wisata Telaga Biru yaitu penyediaan sarana dan prasarana wisata telaga biru, rencana tambahan promosi, pembentukan pengurus tetap, koordinasi dengan sektor pendukung pariwisata, pelaksanaan promosi pariwisata nusantara terutama di dalam negeri dan pelatihan pemandu wisata. (2) Kendala yang dihadapi pemerintahan desa Tanjung Alam dalam pengembangan wisata Tanjung Alam adalah keterbatasan dana, rendahnya kualitas SDM (sumber daya manusia) pengelola dan Peran Pemerintah Daerah Kabupaten Merangin yang belum aktif dalam mendukung penyediaan sarana dan prasarana kegiatan wisata.

Berdasarkan hasil penelitian yang dilakukan oleh penulis terkait dengan pengembangan obyek wisata, maka saran yang dapat diberikan dalam penelitian ini adalah agar sekiranya pengembangan yang dilakukan terkait dengan obyek wisata Telaga Biru dapat terealisasi secepatnya, pengelolaan lebih profesional, dirumuskan dalam Perda dan adanya tambahan sarana dan prsarana wisata sehingga baik pemerintah, wisatawan dan terlebih lagi masyarakat setempat dapat merasakan manfaat yang besar dari pengembangan yang dilakukan tersebut.

\section{Referensi}

Bracker, J. (1980). The Historical Development of the Strategic Mnagement Concept. Academy of Management Review, 5(2).

Hadiwijoyo, S. S. (2012). Perencanaan Pariwisata Perdesaan Berbasis Masyarakat; Sebuah Pendekatan Konsep. Graha Ilmu.

Mintzberg, L., \& Quinn, G. (2003). The Strategy Process" edisi keempat. New Jersey Upper Saddle River.

Nizar, M. A. (2011). Pengaruh pariwisata terhadap pertumbuhan ekonomi di Indonesia.

Rahma, A. A. (2020). Potensi Sumber Daya Alam dalam Mengembangkan Sektor Pariwisata di Indonesia. Jurnal Nasional Pariwisata, 12(1), 1-8.

Sastrayuda, G. S. (2010). Konsep Pengembangan Kawasan Desa Wisata dalam Hand Out Mata Kuliah Concept Resort and Leisure, Strategi Pengembangan dan Pengelolaan Resort and Leisure. Diunduh Dari Www. File. Upi. Edu.

Suwantoro, G. (2004). Dasar-dasar pariwisata.

Suyanto, M. R. P. (2012). KUALITAS PERAN DAN KAPASITAS KETERLIBATAN MASYARAKAT SEBAGAI FAKTOR PENDUKUNG KEBERDAYAAN MASYARAKAT DALAM PENGEMBANGAN KEPARIWISATAAN Studi Kasus DESA WISATA KEBONAGUNG, KABUPATEN BANTUL, DIY. Universitas Gadjah Mada. 
Tjiptono, F. (2008). Strategi Pemasaran (edisi III). Andi.

Yoeti, A. O. (2006). Perencanaan Strategis Pemasaran Daerah Tujuan Wisata. PT. Pradaya Paramita.

Yoeti, A. O. (2008). Perencanaaan dan Pengembangan Pariwisata. Pradaya Pratama. 